Article

\title{
Impacts of Consumers and Real Estate Enterprises on the Implementation of Prefabrication in Residential Buildings: The Moderating Role of Incentive Policies
}

\author{
Jingyang Zhou ${ }^{1}$, Yanjun Qin ${ }^{1, *}$ and Shaoze Fang ${ }^{2}$ \\ 1 School of Management Engineering, Shandong Jianzhu University, Jinan 250101, China \\ 2 College of Management and Economics, Tianjin University, Tianjin 30072, China \\ * Correspondence: qinyanjun1992@163.com
}

Received: 5 August 2019; Accepted: 31 August 2019; Published: 4 September 2019

check for updates

\begin{abstract}
Based on the theory of Planned Behavior, this study firstly explored the relationship between the behavioral intention and the actual behavior of consumers and real estate enterprises when choosing prefabricated residential buildings. Partial Least Squares Structural Equation Modeling (PLS-SEM) was adopted, being supported by the questionnaire data from 310 respondents of 14 prefabricated building demonstration cities in China, to achieve the purpose. The results show that there is a gap between the behavioral intention and the actual behavior of consumers and real estate enterprises. The moderating effect of reputational incentive policies and financial incentive policies was examined to bridge the gap. It shows that reputational incentive policies and financial incentive policies are an effective way in promoting the behavioral intention and actual behavior of real estate enterprises when adopting prefabricated residential buildings, but they all do not work for consumers. The findings can help government understand the preference of consumers and real estate enterprises, so as to use governance incentive policies more wisely and rationally under various circumstances.
\end{abstract}

Keywords: prefabricated residential building; theory of planned behavior; reputational incentive policy; financial incentive policy

\section{Introduction}

Within the construction industry, the concept of sustainable development has become a vital factor for making decisions [1]. Prefabricated technology has many advantages when compared with traditional construction methods, which mainly include fewer material waste, lower noise and dust, reduction in labor demand, and high construction productivity [2]. Prefabricated construction technology has been widely applied in many countries and regions, especially in developed entities [3]. As a result, there has been a more than $60 \%$ prefabricated rate of buildings in developed countries, such as the United States, Japan, the United Kingdom, and Singapore [4]. The advantages of prefabricated construction method has also attracted the attention of developing countries, such as China, which is experiencing a paradoxical process with rapid urbanization and serious environmental problems being caused by construction activities [5]. The governments of developing countries launched many compulsory or incentive policies to improve the application of this revolutionary technology. The prefabricated construction method has been regarded as a national strategic task for China to achieve the goal of green building and industrialization of construction. Under the guidance of this strategy, the 13th Five-Year Planned Construction Action Plan was issued by the Ministry of Housing and Urban-Rural Development of China, in which the goal that the proportion of newly-built prefabricated buildings should reach more than $15 \%$ by the end of 2020 was set. However, prefabricated construction technology was mainly applied to the projects that were invested by government. As the critical support for the 
efficient implementation of prefabricated construction method, few real estate companies progressively implement this technology in their residential buildings actively. There exists embarrassment between incentive policies from governments and the reluctance of real estate enterprises.

The gaps in the implementation of prefabricated building have also drawn the great concern of scholars around the world. Many scholars imputed the gap to the lack of regulations and effective incentive policies from the government [6-8]. Therefore, [9] pointed out that more attention should be paid to eliminate the inadequacy of incentives and regulations in the promotion of prefabricated construction method. The above viewpoints on the obstacles in the implementation of prefabrication were also echoed by other scholars $[10,11]$. Moreover, it is also aware that the interest and demand of consumers are vital factors that cannot be ignored, because the production method largely depends on the consumption patterns of consumers [12]. It is obvious that real estate enterprises would be reluctant to implement the prefabricated method if consumers are not interested in it [13]. The findings of previous studies indicate that consumers and enterprises have strong behavioral intention to make pro-environmental purchase decisions or carry out green environmental strategies $[14,15]$. However, there is sufficient evidence that strong green consciousness was not shifted to actual behavior well for various constraints [16,17]. Moreover, previous studies related to the behavior research of participants of prefabricated buildings did not strictly distinguish behavioral intention and actual behavior. Therefore, understanding the gap between what consumers and real estate enterprises intend to do and what they actually do, and examining how to close this gap are clearly important academic, managerial, and social missions.

Reputational incentives and financial incentives are two typical incentive policies that play different roles in promoting prefabrication. However, the results of existing studies that are related to the impacts of incentive policies in promoting the implementation of prefabrication are inconsistent and ambiguous [18,19]. As an implicit incentive mechanism, reputational incentive policies have a strong positive effect on the contractors and other participants of a construction project. Reputational incentives can help enterprises to enhance their market competitiveness or bargaining power, and thus gain long-term profits [20]. Financial incentive policies have been embodied in many countries and regions, such as Malaysia and Singapore. In 2010, the government of Malaysia announced Green Technology Financing Scheme (GTFS), which provided soft loan incentive for innovators and practitioners who participated in the implementation of green construction technologies. Under the motivation of this policy, the prefabricated construction method and other green building technologies have attracted more and more attention and the green building certification rate in Malaysia increased from 1 to 137 between 2009 and 2013 [4]. Singapore is the first country proposing compulsory requirements to promote the application of prefabrication. Specifications for assessing the buildings' quality and testing the "buildability" were compiled under the guidance of Buildable Design Assessment System (BDAS) [21]. These previous studies provided a descriptive analysis on the impacts of incentive policies in the promotion of the prefabricated construction method. No efforts have been devoted to evaluate the effectiveness of the reputational incentives and financial incentives, especially in promoting the consumers' purchasing behavior and the implementation of prefabricated method in real estate enterprises.

To fill up this gap, this paper attempts to answer two questions. First, the relationships between behavioral intention and actual behavior when choosing prefabricated residential buildings would be explored from the perspectives of consumers and real estate enterprises, respectively. For the perspective of consumers, it focuses on the relationship between the behavioral intention of purchasing prefabrication (BIP) and the actual behavior of purchasing prefabrication (ABP). For real estate enterprises, it concerns the relationship between the behavioral intention of implementing prefabrication (BII) and the actual behavior of implementing prefabrication (ABI). Second, the moderating effects of reputational incentives and financial incentives on the relationships that were explored in the first step would be examined for understanding the factors that affect the realization of behavioral intention into actual behavior. The remaining parts of this paper are structured, as follows: Section 
"Conceptual Framework" provides the theoretical background. Then seven hypotheses are proposed, and the conceptual model is established for empirical testing; Section "Methodology" presents the research methodology and design, followed by Section "Data Analysis and Results", which presents the analytical results of the structural model; finally, the findings of this paper, its conclusions, implications, and limitations are provided in Sections "Discussion" and "Conclusions and Implications" respectively.

\section{Conceptual Framework}

A conceptual model that is underpinned by the Theory of Planned Behavior and five streams of studies, namely reputational incentives, financial incentives, BIP, ABP, BII, and ABI.

\subsection{Theory of Planned Behavior}

The Theory of Reasoned Action (TRA) was proposed by Ajzen and Fishbein, which assumed that people would make rational choice under complete volitional control in their decision-making process [22]. Furthermore, there is a high correlation between behavioral intention and actual behavior. The Theory of Planned Behavior (TPB) was expanded from TRA by Ajzen in 1985 [23]. It emphasizes that behavioral intention does not always lead to actual behavior because of the limitation of actual control conditions, such as personal abilities, opportunities, and resources. In other words, behavioral intention cannot be the only factor that determines actual behavior [24,25]. Sometimes, human behavior can also be determined by non-volitional factors. TPB assumes that not only volitional control, but also non-volitional control, can explain the factors that influence individual behavior. Intention is a central factor of the TRA and TPB [26]. Behavioral intention is affected by three interrelated factors. The first is attitude which is expressed in people's beliefs, emotions, and tendencies [27]. The second is the subjective norm, which refers to the perceived social pressures about whether to take a specific behavior [28,29]. The third one is the perceived behavioral control that can be applied together with behavioral intention to predict behavior. It is people's perceptions of their ability to perform a given behavior through past experience and predicted obstacles [30]. In this study, behavioral intention means that customer's willingness to purchase prefabricated residential buildings or the willingness of real estate enterprises to development prefabricated buildings. TPB would be more appropriate than TRA in exploring the relationship between behavioral intention and actual behavior in this study. For example, customers have a high willingness to purchase prefabricated residential buildings, but they would not do it if they cannot afford the price, or if the location of the prefabricated residential building is not convenient. For real estate enterprises, although they have a high willingness to develop prefabricated residential buildings, they cannot implement it in their projects if consumers' enthusiasm to purchase is not high, or the cost of implementing prefabrication is too high. It is clear that many non-volitional factors may diminish the opportunity to make a decision to choose prefabricated buildings for consumers and real estate developers. Therefore, a TPB-based conceptual framework would be designed to provide a clear structure that allows the authors to explore the relationship between behavioral intention and actual behavior by simultaneously considering the moderating role of reputational incentives and financial incentives.

\subsection{Hypotheses for the Conceptual Framework}

In this section, three kinds of relationships, namely the effects of BIP on ABP, the effects of ABP on $\mathrm{ABI}$, and the effects of BII on ABI, and the moderating role of reputational incentives and financial incentives on the relationships are systematically and theoretically analyzed. Accordingly, seven hypotheses regarding the relationships are proposed. Moreover, the research variables that support the proposed relationships are also reviewed.

\subsubsection{Effects of BIP on $\mathrm{ABP}$}

Since the 1970s, many scholars have attempted to elaborate on the concept of green consumption [31-33]. The findings showed that social initiatives, government policies, and technologies 
have considerable influence on green consumption intention, thereby changing the pattern of consumer behaviors. Purchasing prefabrication is an important embodiment of environmental protection and environmental responsibility [34].

Attitude, subjective norm, and perceived behavioral control can affect behavioral intention. A positive environmental attitude can directly influence pro-environmental behavior. Some studies related to consumers' behavior show that knowledge shapes attitudes, which then shapes behavior, which is the basis of TPB [33,35]. Proper educational programs and increased environmental knowledge of consumers can change their preferences and cultivate a positive attitude toward green consumption behaviors [36]. Subjective norm is considered to be a function of normative beliefs and the motivation to comply. Normative beliefs refer to perceived behavioral expectations from an important reference, such as family, friends, relatives, or neighbors. Motivation to comply includes a person's desire to consider the opinions of important referents on a behavior [22]. Thus, in our context, when significant others view purchasing prefabricated residences as proper behavior, one's perceived social pressure to purchase prefabricated residences would increase with his/her motivation to comply. Numerous studies have indicated that consumer behaviors are influenced by their self-confidence in their ability to perform the behavior [37-39]. The results of these studies show that, when consumers hold more control over carrying out a certain behavior because of sufficient required resources, they tend to carry out this behavior.

As above, behavioral intention is the premise of the actual behavior of consumer purchasing prefabrication and Hypothesis 1 is proposed.

Hypothesis 1 (H1). BIP has a positive effect on $A B P$.

\subsubsection{Effect of $A B P$ on $A B I$}

Green consumption is a kind of guiding consumption. The profits of enterprises depend on consumer purchasing behaviors. The preferences and choices of consumers will have an important effect on the enterprises [40]. The purchasing behaviors of consumers is the driving force for real estate enterprises to change their concepts and implement prefabrication. In addition, while the implementation of prefabrication involves multiple stakeholders, the purchasing behaviors of consumers have the greatest effect on the implementation of prefabrication in real estate enterprises [41]. If consumers have a tendency towards prefabrication, the motivation to implement prefabrication for real estate enterprises is stimulated. As a result, Hypothesis 2 is proposed.

Hypothesis 2 (H2). ABP has a positive effect on ABI.

\subsubsection{Effect of BII on ABI}

The growing concern over the various negative environmental effects of the building industry in China is changing the competitive pattern of the construction market and prompting enterprises to produce in a "greener" way [42]. Currently, the market environment is driving Chinese enterprises to adopt environmental technology. More and more enterprises strive to present their products in an environmentally friendly way [43]. Generally, enterprises formulate their strategy for developing environmental technology in cooperation with their main stakeholders [44]. Prefabricated technology is also considered to be a new path of sustainable development in China for its potential for reduced environmental pollution and proven efficiency [45]. In this study, if real estate enterprises have a good perception to implement prefabrication, they will implement prefabrication. The social pressure was expected to influence the preference of real estate enterprises to implement prefabrication. Perceived behavioral control is the perception of real estate enterprises to control the implementation of prefabrication. What real estate enterprises perceived about their control to implement the prefabrication was expected to influence their intention to implement prefabrication. Therefore, Hypothesis 3 is proposed. 
Hypothesis 3 (H3). BII has a positive effect on ABI.

\subsubsection{Moderating Roles of Reputational Incentives and Financial Incentives}

In general, incentives can be described as tools that influence people's behavior [46]. Lack of interest and demand is the main obstacle on the adoption of green strategies in the Chinese construction industry as consumers are a key factor influencing the prosperity of the prefabrication market [47]. As revealed by previous research, the government can utilize reputational incentives to promote socially responsible consumption awareness [48,49]. After consumers purchase "green" products they may be in "conspicuous conservation", especially they start to consider their responsibilities and reputation [32]. Reputational incentives encourage consumers to continuously choose green products. If education and reputation work together, it will play a better guiding effect on people's behavioral intention. This education increases reputational pressures effectively [50]. As a result, the positive relationship between BIP and ABP might be strengthened by government reputational incentives. Hypothesis 4 is proposed.

Reputational incentives have played a critical role in promoting the implementation of prefabrication in residential buildings [51]. Reputational incentives can improve the renown of real estate enterprises. Moreover, real estate enterprises have priority over others in obtaining pre-sale permission for commercial housing and they give priority to prefabrication when government rewards high-quality projects and excellent engineering design. These incentives allow for real estate enterprises to benefit early from the development of prefabrication. Reputational incentives concentrate on propagating the potential benefits of prefabrication for real estate enterprises, rather than promising real benefits compensation. Companies are concerned with their reputation in the market, which could be reflected in their responsibility for society [27]. Enterprises will strengthen their investment in environmentally friendly products and innovation to improve their environmental performance and demonstrate a responsible corporate image [52]. Enterprises are influenced by the expectations of stakeholders in promoting an appropriate eco-friendly technology strategy [53]. Good reputation usually yields market advantages, such as enhancing green investment enthusiasm and improving product popularity, which leads to better consumer opinion [54]. Real estate enterprises that implement prefabrication can develop a good reputation in society, which can increase the value of the corporate brand [55]. Based on these points, Hypothesis 5 can be proposed.

According to the egoistic values, consumers decide whether to embrace green consumption behaviors based on its costs for the individual $[56,57]$. Most people prefer consumption behaviors that incur lower economic costs [58,59]. People generally want to do the right thing, but their priorities change when they have to pay for it. This is consistent with Maslow's hierarchy of needs theory. Only when people meet their individual needs do they become more likely to embrace ecological behavior, because they have more time and money to care about social and environmental problems. In addition, the price of green products is usually higher than traditional products, which is the main reason why consumers are reluctant to accept green products [18]. Previous research has proposed that government departments should formulate specific financial incentives to encourage consumers to embrace green consumption behaviors $[60,61]$. Thus, the positive relationship between the BIP and $A B P$ will undoubtedly be strengthened with higher levels of financial incentives, as proposed in Hypothesis 6.

Financial incentives include various financial subsidies, tax credits, and land support offered to prefabrication practitioners. Managers of real estate enterprises consider the high initial cost and lack of government financial incentives as the main obstacles in implementing a green strategy for residential projects [7]. The government acts as a promoter in the development of prefabrication who has a number of incentive policy tools [62]. Presently, most of the current financial policies from an encouraging direction guide real estate enterprises in implementing prefabrication. Financial incentives have been the main driving force to adopt green innovation strategies and practices for real estate enterprises [63]. Shazmin, Sipan and Sapri [64] stated that financial incentives, such as property tax assessment, which 
have been adopted widely by several commonwealth countries, including Spain, Romania, Italy, Bulgaria, the United States, Canada, Malaysia, and India, would be an effective means of promoting the development of prefabrication and other kinds of green building methods. The Hong Kong Buildings Department issued a series of financial incentive policies to promote the development of prefabrication, in which the reward of gross floor area (GFA) has the greatest attraction for real estate enterprises. Based on the policy, real estate enterprises can increase the volumetric rate of their projects to gain additional GFA if they adopt prefabricated construction methods, such as non-structural external walls [65]. Strengthening government financial incentives can increase the enthusiasm of real estate enterprises to implement prefabrication. The evolution process of prefabrication can be divided into three typical stages after studying the development of the construction industry in developed countries: initial stage, development stage, and mature stage [66]. Prefabrication, as new technology, is inseparable from the support of the government in the initial stage. The government provides incentives to entice stakeholders to adopt prefabrication [67]. The development of prefabrication in China is still in its infancy, and thus, incentive policies, including compulsory and optional measures, have been carried out by the government to raise awareness of prefabrication in real estate enterprises in China [68]. The positive relationship between BII and ABI in residential buildings might be strengthened by higher levels of financial incentives, and thus Hypothesis 7 is proposed.

The following hypotheses are proposed:

Hypothesis 4 (H4). Reputational incentives will positively moderate the relationship between BIP and ABP.

Hypothesis 5 (H5). Reputational incentives will positively moderate the relationship between BII and ABI.

Hypothesis 6 (H6). Financial incentives will positively moderate the relationship between BIP and ABP.

Hypothesis 7 (H7). Financial incentives will positively moderate the relationship between BII and ABI.

\subsection{Conceptual Model}

Based on the above statements and hypotheses, a conceptual model on the relationship between BIP and ABP, as well as the link between BII and ABI was developed, as shown in Figure 1. The model includes two moderating variables—-reputational and financial incentives-for the relationship between behavioral intentions and behavior. It illustrates the possible influence path of reputational and financial incentives on implementation of prefabrication in residential buildings. Seven hypotheses are to be tested based on the model.

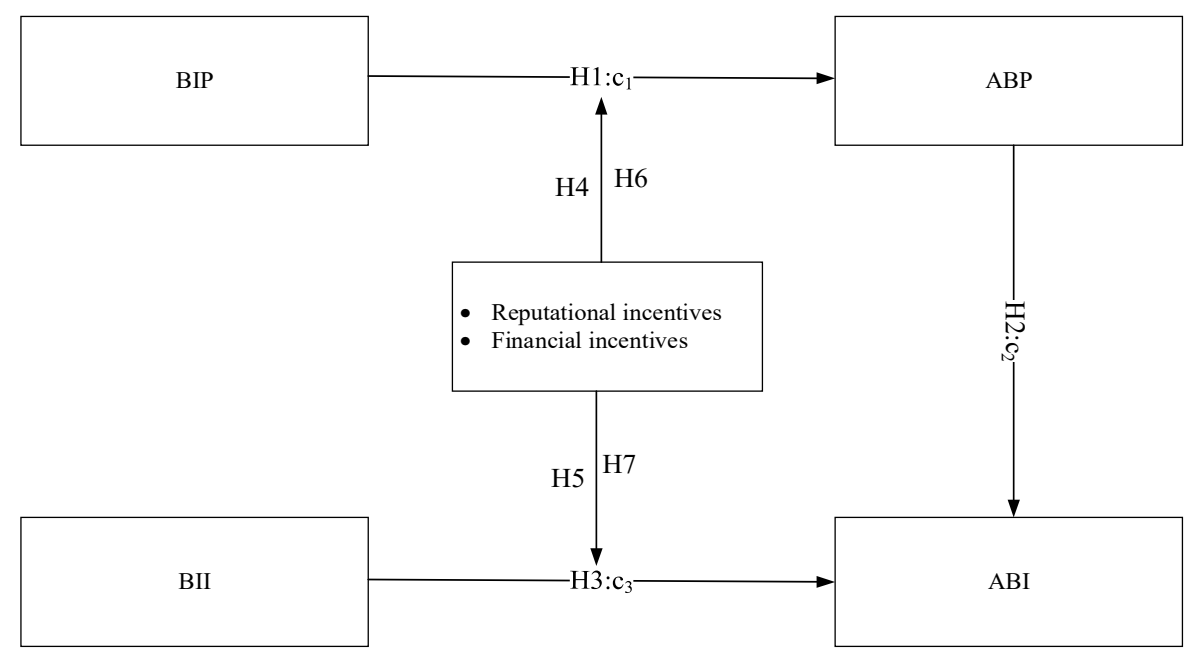

Figure 1. Conceptual model. 


\section{Methodology}

This section outlines the main steps of the methodological approach. The conceptual model has been built up based on the seven hypotheses that are mentioned above. First, Partial Least Squares Structural Equation Modeling (PLS-SEM) was explained as an appropriate method to analyze the data. Subsequently, items were clarified to measure the constructs. After that, data was collected through a questionnaire survey to verify the seven hypotheses, the concrete information of data collection process was introduced. Finally, Smart PLS 3.0 was used to test the reliability and validity of the data and calculate the significance of each Hypothesis.

\subsection{Method}

PLS-SEM supported by questionnaire survey data were applied to test these hypotheses. In general, there are two major approaches of structural equation modeling (SEM) for analyzing cause-effect relations between latent constructs, namely, partial least squares structural equation modeling (PLS-SEM) and covariance-based structural equation modeling (CB-SEM). The differences between them are embodied not only in the basic assumptions, but also in their procedures [69]. PLS-SEM can be considered to be an alternative CB-SEM for estimating theoretically established cause-effect relationship [70]. It has gained a great momentum and been applied in a variety of research fields [71,72]. Accordingly, PLS-SEM can also be more appropriate in this research for the following two reasons. Firstly, the latent variables that are mentioned in the conceptual/model have been discussed in many green consumption-related publications [38,73]. However, there are few studies that focus on analyzing the statistical relationship between these latent variables and their impact on the implementation of prefabrication in real estate enterprises. It caused an increasing complexity when analyzing the cause-effect relationships. PLS-SEM is particularly useful in analyzing research models, which remain at the exploratory stage [74]. Therefore, PLS-SEM can meet the challenges that are faced by this research. Secondly, PLS-SEM makes no particularly no assumption regarding the underlying data, such as the data collected for this study. The data can be non-normal when applying the PLS-SEM method. Moreover, PLS-SEM is the primary choice when analyzing such data and it has stronger statistical analysis ability than CB-SEM.

\subsection{Measures}

Measures of behavioral intention and actual behavior were adopted or adapted from the existing literature that have been repeatedly used in various contexts and different kinds of samples. Table 1 presents a complete list of the scale item. The five-point Likert-scale was used to assess the conformance level for respondents $(1=$ strongly agree; 2 agree; $3=$ medium; $4=$ disagree; and, $5=$ strongly disagree). Table 2 shows all of the items. Three items (BIP1-BIP3) $[75,76]$ were used to assess BIP. Three item (ABP1-ABP3) [77,78] were used to assess ABP. Three items (BII1-BII3) [79] were used to assess BII. Three item (ABI1-ABI3) [80] were used to assess ABI.

Table 1. Measures of constructs.

\begin{tabular}{cl}
\hline Constructs & \multicolumn{1}{c}{ Items } \\
\hline \multirow{2}{*}{ BIP } & BIP1 I will take the initiative to understand the advantages of prefabrication \\
\cline { 2 - 2 } & $\begin{array}{l}\text { BIP2 I will recommend relatives and friends to purchase prefabricated residence actively } \\
\text { BIP3 I will promote the advantages of prefabrication to relatives and friends }\end{array}$ \\
\hline ABP & $\begin{array}{l}\text { ABP1 I have purchased prefabricated residence } \\
\text { ABP3 When I am ready to buy residence, I will always choose to purchase prefabricated } \\
\text { residence in the future }\end{array}$ \\
\hline
\end{tabular}


Table 1. Cont.

\begin{tabular}{cl}
\hline Constructs & \multicolumn{1}{c}{ Items } \\
\hline \multirow{2}{*}{ BII } & BII1 I think it's a good opportunity to develop prefabrication \\
\cline { 2 - 2 } & BII2 The prefabricated market is expected to be more prosperous in the future \\
\cline { 2 - 2 } ABI & BII3 I will advocate the development of prefabrication actively \\
\cline { 2 - 2 } & ABI2 We will develop prefabrication certainly \\
\hline & ABI3 We will continue to develop prefabrication in the future \\
\hline
\end{tabular}

Table 2. Background information of respondents.

\begin{tabular}{cccc}
\hline Feature & Type & Number & Percentage \\
\hline \multirow{3}{*}{ Age } & $18-30$ years & 86 & $27.8 \%$ \\
& $31-40$ years & 104 & $33.5 \%$ \\
& $41-50$ years & 70 & $22.6 \%$ \\
& $51-60$ years & 50 & $16.1 \%$ \\
\hline \multirow{2}{*}{ Gender } & Female & 122 & $39.4 \%$ \\
& Male & 188 & $60.6 \%$ \\
\hline \multirow{3}{*}{ Education } & High school & 32 & $10.3 \%$ \\
& University & 174 & $56.1 \%$ \\
& Master's degree & 82 & $26.5 \%$ \\
& PhD or above & 22 & $7.1 \%$ \\
\hline \multirow{3}{*}{ Monthly income } & $<3000$ & 18 & $5.8 \%$ \\
& $3001-5000$ & 72 & $23.2 \%$ \\
& $5001-10,000$ & 128 & $41.3 \%$ \\
& $10,001-20,000$ & 62 & $20.0 \%$ \\
& $>20,000$ & 30 & $9.7 \%$ \\
\hline
\end{tabular}

\subsection{Sampling and Data Collection}

This research collected data through a questionnaire survey that was sent through email or through an interview. The respondents were project managers who had a good understanding of the prefabrication and development authority and consumers planning to buy a house. However, most people are unfamiliar with the concept of reputational incentive. As a result, consumers tend to be young or middle-aged people with a bachelor's degree or above. The respondents were asked to fill out questionnaires in the context of non-incentives, reputational incentives, and financial incentives according to their own experiences.

Local governments, such as Beijing, Shanghai, Shenzhen, and other provinces that have set development goals of implementing prefabrication, echoed incentive policies. By the end of 2018, more than 30 provinces had launched incentive policies to achieve their short-term or long-term development goal of prefabrication. The Chinese government has also identified and approved some demonstration cities to promote the development of prefabrication. Data were collected from 14 demonstration cities in China (Beijing, Shanghai, Tianjin, Nanjing, Shenzhen, Hangzhou, Changsha, Hefei, Xinxiang, Jinan, Yantai, Weifang, Qingdao, and Jining). The prefabrication market in the demonstration cities can be viewed as an authentic depiction of China. A total of 520 questionnaires were sent out and 340 questionnaires were returned. Among the returned questionnaires, real estate enterprises managers answered 163 and the consumers answered 177. Eight invalid surveys answered by managers and 22 invalid surveys answered by consumers were removed and, thus, the final effective response rate is $59.62 \%$. The investigation process occurred between January 2019 and May 2019. A diverse range of consumers and real estate enterprises were identified from the collected data, 
thereby guaranteeing that a representative sample was obtained. Table 2 shows the demographic breakdown of all the respondents.

\section{Data Analysis and Results}

\subsection{Reliability and Validity Test of the Data}

The reliability and validity tests of BIP, $\mathrm{ABP}, \mathrm{BII}$, and $\mathrm{ABI}$ were conducted for ensuring the availability and usability of the collected data. The reliability was assessed based on internal consistency reliability (Cronbach's alpha) and composite reliability (CR). When the CR values and Cronbach's alpha values are higher than 0.7 , it can be considered that the collected data are suitable and reliable for the research. As shown in Table 3, the CR values and Cronbach's alpha values for the four variables are both higher than 0.7 , which indicates that the internal consistency and composite reliability in this research reach the threshold values. Convergent validity and discriminate validity were used to assess the validity of the collected data based on the value of average variance extracted (AVE). It is considered to be valid when the AVE value of the latent variable is higher than 0.5. The results of the AVE values in Table 4 show that convergent validity test can be passed. To satisfy the criterion of discriminant validity, the Fornell-Larker criterion that the square roots of AVE in diagonals should be higher than the off-diagonal elements in the corresponding rows and columns. As shown in Table 4 , the values meet the criterion of discriminant validity and the validity is acceptable.

Table 3. Results of the measurement model.

\begin{tabular}{cccc}
\hline Constructs & Cronbach's $\alpha$ & CR & AVE \\
\hline BIP & 0.87 & 0.92 & 0.77 \\
ABP & 0.78 & 0.85 & 0.81 \\
BII & 0.84 & 0.87 & 0.69 \\
ABI & 0.92 & 0.93 & 0.78 \\
\hline
\end{tabular}

Table 4. AVE values and correlations of the constructs.

\begin{tabular}{ccccc}
\hline Criterion & BIP & ABR & BIR & ABR \\
\hline BIP & 0.877 & & & \\
ABP & 0.551 & 0.900 & & \\
BII & 0.427 & 0.382 & 0.831 & \\
ABI & 0.632 & 0.432 & 0.438 & 0.883 \\
\hline
\end{tabular}

\subsection{The Verification of All the Hypothesis}

The $\mathrm{R}^{2}$ value of PLS-SEM structure model was applied as the main criterion and measure to explain the changes of endogenous potential variables and to evaluate the model's predictive accuracy. The $\mathrm{R}^{2}$ value ranges from 0 to 1 , with higher levels manifesting in a greater degree of predictive accuracy. It is generally acknowledged that the fitting degree of the model can be accepted when the $R^{2}$ value is more than 0.33. In the research, the $R^{2}$ values for the two dependent variables ABP and $\mathrm{ABI}$ are 0.356 and 0.624 , respectively. Based on the data from questionnaire survey and Smart PLS 3.0 analysis software, the effect of BIP on ABP, the effect of ABP on the ABI, and the effect of BII on ABI were obtained, as shown in Figures 2-4. The three figures demonstrate the relationships between the variables under the conditions of "with non-incentives", "with reputational incentives", and "with financial incentives", respectively.

To test the significance of moderating role of reputational incentives and financial incentives, multi-group analysis (MGA) was conducted to compare the bootstrap coefficients from two separate groups: "with non-incentives" and "with reputational incentives", as well as "with non-incentives" and "with financial incentives". 
Under the condition of "with non-incentives", as shown in Figure 2, BIP has no significant effect on $\mathrm{ABP}\left(\mathrm{c}_{1}=0.132, \mathrm{~T}=1.32\right)$. ABP has a significant effect on $\mathrm{ABI}\left(\mathrm{c}_{1}=0.292, \mathrm{~T}=4.35\right)$. BII has no significant effect on ABI $\left(c_{1}=0.216, T=1.58\right)$. Therefore, Hypothesis $\mathrm{H} 1$ and $\mathrm{H} 3$ are not supported and Hypothesis $\mathrm{H} 2$ is supported.

Under the condition of "with reputational incentives", as shown in Figure 3, BIP has no significant effect on $\mathrm{ABP}\left(\mathrm{c}_{1}=0.197, \mathrm{~T}=1.36\right)$. ABP has a significant effect on $\mathrm{ABI}\left(\mathrm{c}_{1}=0.312, \mathrm{~T}=4.97\right)$. BII has a significant effect on ABI $\left(c_{1}=0.388, T=8.62\right)$. The effect of BIP on ABP still remains non-significant when compared with the results of "with non-incentives", which illustrates that reputational incentives have a weak moderating effect on this path. Therefore, $\mathrm{H} 4$ is not supported. The positive effect of $\mathrm{ABP}$ on $\mathrm{ABI}$ is more intense. On the contrary, the effect of BII on ABI changed from insignificant to significant, which illustrates that reputational incentives play a moderate role in improving the implementation of prefabricated buildings. Therefore, Hypothesis $\mathrm{H} 5$ is supported.

Under the condition of "with financial incentives", as shown in Figure 4, whether the influence path between ABP and ABI $\left(c_{1}=0.329, \mathrm{~T}=7.41\right)$ or the path between BII and ABI $\left(c_{1}=0.427, \mathrm{~T}=10.13\right)$, they both have significant relationships of influence. However, as compared with the results of "with non-incentives", the effect of BIP on ABP $\left(c_{1}=0.188, T=1.78\right)$ still remains non-significant, which indicates that financial incentives have no moderating effect on this path. Therefore, the Hypothesis $\mathrm{H} 6$ is not supported. The effect of ABP on ABI is strengthened. The effect of BII on ABI changed from non-significant to significant, which provides sufficient evidence for verifying Hypothesis H7.

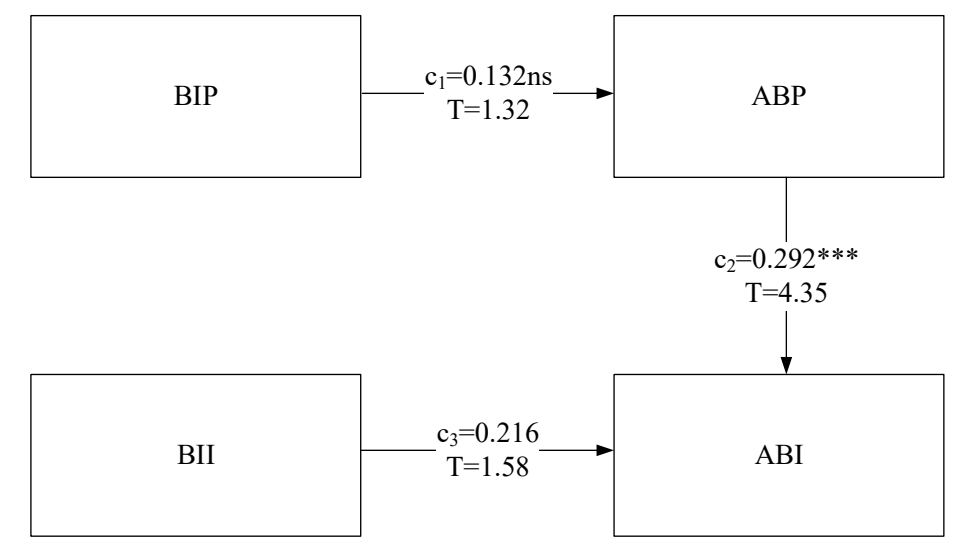

Figure 2. Results of the structural model with non-incentives. Note: ${ }^{* * *} p<0.001$; and, n.s. $=$ not significant.

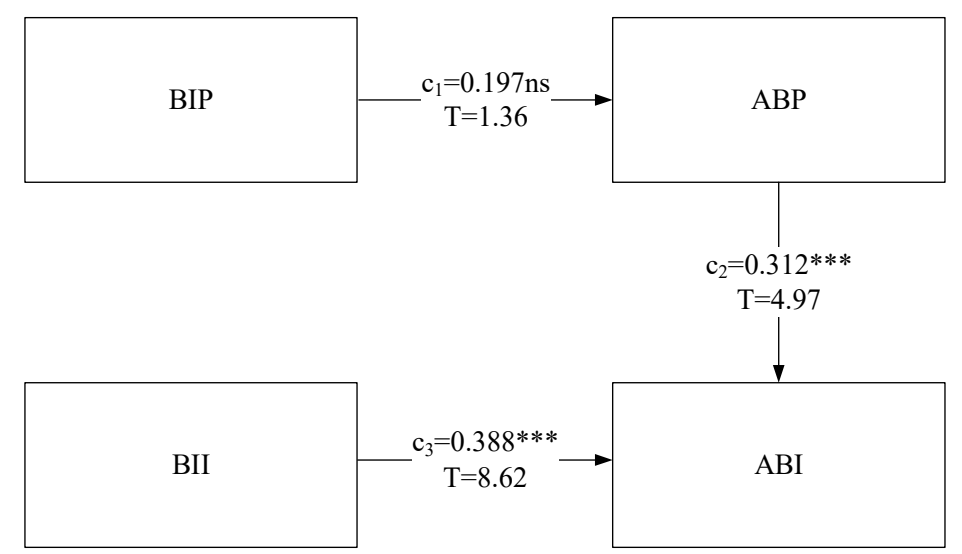

Figure 3. Results of the structural model with reputational incentives. Note: ${ }^{* * *} p<0.001$; and, n.s. $=$ not significant. 


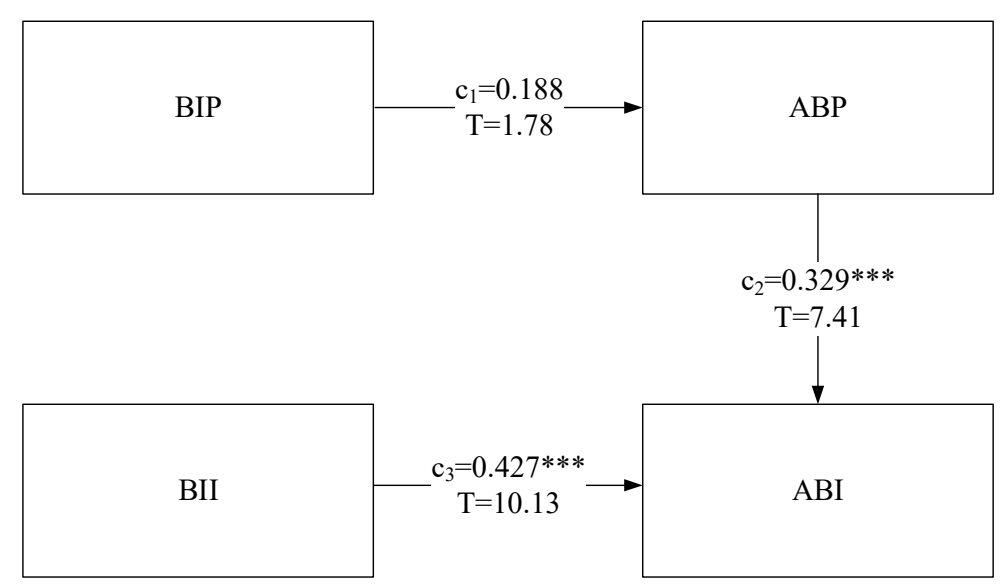

Figure 4. Results of the structural model with financial incentives. Note: ${ }^{* *} p<0.001$; and, n.s. $=$ not significant.

\section{Discussion}

Overall, based on TPB, this study used PLS-SEM for exploring the relationship between the behavioral intention and actual behavior of consumers and real estate enterprises when choosing prefabricated residential buildings, and assessing the moderating role of reputational incentives and financial incentives on the changes of their choices.

The results show that there are non-significant relationships of influence between the behavioral intention and the actual behavior of choosing prefabricated buildings under the condition of "with non-incentives", whether for consumers or real estate enterprises. It means that the behavioral intention and behavior are inconsistent for consumers and real estate enterprises. Their behavioral intentions cannot be upgraded to their actual behaviors of choosing prefabricated buildings. For consumers, it can be attributed to the following reasons. First, price is a crucial factor that influences the sale of prefabricated residential buildings. Grimmer [33] pointed out that the purchasing behaviors of consumers are closely related to their income, the expected price, and the expected benefits that are gained from prefabricated residential buildings. If the price of prefabrication is too high and it exceeds the range that consumers can afford, the purchasing behaviors of consumers may be reduced, although many consumers have the willingness to purchase a prefabricated residential building. Another important reason is that there are relatively few real estate enterprises that are engaged in construction of prefabricated residential buildings, which leads to prefabricated residential buildings are in short supply, however meanwhile, discounts and promotion activities of traditional residences are drawing in more consumers. Second, there is a lack of knowledge for many consumers in understanding prefabricated residential buildings, which causes them to worry about the living convenience and quality of the prefabricated residential buildings to some extent [81]. Hypothesis $\mathrm{H} 2$ was verified based on the results, which means that the actual purchasing behaviors of consumers can positively affect the actual implementing behaviors of real estate enterprises. It indicates that real estate enterprises will fully consider the actual consuming behaviors of consumers, and accordingly adopt corresponding development strategies. Consumers' demands and cravings, current purchasing patterns, as well as unmet latent preference will become the most important factors in the determination of corporate strategy between consumers and real estate enterprises. Consumers can change their purchasing choices and real estate enterprises can optimize their selection of offerings. Therefore, consumers' purchasing choices drive the corporate selection [12]. As China's real estate market is becoming more mature, consumers' demands for the high quality of residential buildings is increasing. As a result, consumers have played a more and more critical role in the development process of real estate industry. Consumption is the ultimate goal and motive force of production [82]; a high acceptance of prefabricated residential buildings of consumers can avoid low sales and can bring higher profits for real estate enterprises. From the unsupported Hypothesis H3, the behavioral intention has no significant 
effect on the actual behavior of implementing prefabrication for real estate enterprises. The reasons for this finding could be due to that the decision makers of real estate enterprises would weigh the gains and losses from the perspective of economic interests. When compared to traditional buildings, real estate enterprises would not take greater risks to implement prefabricated buildings if additional costs are too high for implementing prefabricated buildings. The implementation of prefabricated buildings cannot generate additional profits on sale. Rather than making themselves be in great risk of low sales volume, real estate enterprises are more inclined to the traditional residential buildings.

Under the conditions of "with reputational incentives", the effect of consumers' behavioral intentions on their actual behaviors of purchasing prefabricated buildings still remains non-significant. This result means that consumers do not focus on reputation. It is mainly due to most consumers being economic men, so that they are less likely to pay more attention to the difference of reputation obtained from purchasing prefabricated residential buildings. When people do not fully understand the characteristics and advantages of prefabricated residential buildings, or they cannot experience the convenience of this kind of building, it would be a great risk of property loss for consumers. In the process of purchasing a house, although most consumers think that it is proud to be awarded the title of environmental citizen as a reputational incentive, it is not realistic to be at the expense of their self-economic loss. On the contrary, the behavioral intentions of real estate enterprises have a significant effect on their actual behaviors of implementing prefabricated buildings. Most real estate enterprises hope to enhance their own brand value by establishing a positive image and taking on more social responsibilities [83]. Therefore, improving the reputation of real estate enterprises has become a good incentive mechanism. A good reputation of enterprises can enhance consumers' sense of identification with the enterprises, which can encourage the actual purchasing behaviors of consumers. As mentioned above, consumers' purchasing behaviors can promote the sales of house and thus improve the profits of real estate enterprises. Reputation plays a significant role in the survival, competition, and development of enterprises. With the prefabricated construction market maturing and developing, the real estate enterprises with more government supports in reputation would be willing to take action to implement prefabrication in their projects [84].

The same findings were obtained under the condition of "with financial incentives". The behavioral intentions of consumers have no significant effect on their actual behaviors of purchasing prefabricated residential buildings, while it is effective for real estate enterprises. One of the potential reasons for this finding may be that the government financial incentives are not enough to offset the incremental price of prefabricated buildings. Even in many areas, there are no activities to provide financial incentives for consumers purchasing prefabricated residential buildings. House prices is a huge expense for most consumers; however, the results show that, when compared with the prices of residential buildings, the amounts of financial subsidies are only a small part of the total house price, only when financial subsidies help real estate enterprises slash the prices of prefabricated residential buildings, can actual purchasing behaviors be stimulated effectively. In most areas, financial incentives have not played a significant role in reducing the prices of prefabricated residential buildings and the lack of price advantage leads to the failure of the translation from behavioral intentions to actual behaviors of purchasing prefabricated residential buildings. It is not effective to convince and stimulate consumers to purchase prefabricated residential buildings. Furthermore, consumers are more concerned about the safety of prefabricated buildings. In addition, local governments pay more attention on the financial incentives for real estate enterprises at present. Some relatively rich financial incentives were put into practice for stimulating the enthusiasm of real estate enterprises. Financial subsidies or financing policies from government can significantly alleviate the cost pressure of real estate enterprises to develop prefabricated residential buildings and increase their profits. It can effectively encourage real estate enterprises to develop prefabricated projects and promote the large-scale application of the prefabricated construction method in real estate projects. 


\section{Conclusions and Implications}

This study adopted a questionnaire survey approach to explore the relationship between behavioral intentions and actual behaviors of consumers and real estate enterprises when choosing prefabricated residential buildings, particularly regarding the collective consideration of reputational and financial incentives. Seven hypotheses are proposed in accordance with the theoretical model. The PLS-SEM is used to test the different hypotheses. The findings highlight the large gaps between behavioral intentions and the actual behaviors of consumers and real estate enterprises. The actual purchasing behaviors of consumers was found to have a positive effect on the actual implementing behaviors of real estate enterprises. Reputational and financial incentives both have a weak moderating effect on the relationship between behavioral intentions and actual behaviors of consumers. Reputational and financial incentives play a moderate role in improving the implementation of prefabricated buildings in real estate enterprises.

Different incentive policies have different effects on consumers and real estate enterprises when choosing prefabricated residential buildings. Appropriate incentive measures should be designed based on the different participants of prefabricated buildings. The findings of this paper can provide some meaningful implications for real estate enterprises and governments.

Firstly, a thorough understanding of consumers' behaviors is the basis for formulating advertisement and promotional strategies for real estate enterprises. Prefabricated residential building is a relatively more expensive product for consumers than traditional residential buildings, especially at the primary stage of development. The poor information about prefabricated residential buildings comes from the fragmented information collected from various media because most consumers do not understand the performance of prefabricated buildings and have no experience of using this kind of buildings. It cannot provide sufficient support to consumers for making the purchasing decisions. Therefore, real estate enterprises should try to help consumers gain the knowledge about prefabricated buildings and try to convince them to accept the potential advantages of prefabricated buildings. More attention should be paid to the various forms of advertisements that introduce the characteristics of prefabricated buildings. Moreover, real estate enterprises should actively strive for demonstration projects, constantly create quality projects, foster a good brand image, and induce consumers to purchase prefabricated residential buildings. In addition, real estate enterprises should provide visiting service for consumers. Consumers know more about prefabricated construction technology by visiting the prefabricated factory, which can enhance the confidence of consumers to purchase prefabricated residential buildings.

Secondly, this study also has several implications for government policy makers. Consumers are not sensitive to reputational incentives and financial incentives and any incentive policies have no significant impact on their actual purchasing behaviors, as shown in this research. Although some local governments launched the general incentive policy to arouse consumers' enthusiasm, no specific measures were designed for bringing the policy into force. Therefore, specific and operational implementation plans or incentive standards should be formulated.

Reputational incentives and financial incentives have a significant impact on the choices of prefabricated residential buildings for real estate enterprises. However, the problem is that the exiting incentive policies have been less effective than previously believed. Therefore, the government should consider which kind of incentive polices are more effective for the real estate enterprises. A comprehensive investigation regarding the demands of real estate enterprises should be conducted to provide reference for designing more sufficient incentive measures. Moreover, the government should consider reviewing the prefabrication market and devoting more efforts to stimulate the growth of the prefabrication market and keep the housing price at an affordable level for consumers. Consumers do not need to spend too much efforts and time in searching for prefabricated residential buildings if prefabrication was more widely available in most of sales office. Therefore, incentive or reputational policies should be formulated for improving the prosperity should be strengthened. 
However, although the purpose of the study was achieved, this study has certain limitations. The data in this study were collected in the Chinese context. Whether the conclusions of this paper are applicable to other countries remains to be confirmed due to the differences in national environments and policies. The influencing factors of behavioral intention and actual behavior can be explored further by increasing the survey data of the government. Hence, the measurement questionnaire should be improved and the sample types enriched. What kind of incentives or other measures provided by the government should be brought to follow-up studies.

Author Contributions: J.Z. and Y.Q. conceived and designed the study, analyzed the data and completed the paper. S.F. collected the data.

Funding: This research was funded by Social Science Planning Project in Shandong Province number 19BYSJ17.

Acknowledgments: The authors would like to thank the experts who reviewed the manuscript.

Conflicts of Interest: The authors declared that there were no conflicts of interest to this study.

\section{References}

1. Ji, Y.; Li, K.; Liu, G.; Shrestha, A.; Jing, J. Comparing greenhouse gas emissions of precast in-situ and conventional construction methods. J. Clean. Prod. 2016. [CrossRef]

2. Li, Z.; Shen, G.Q.; Xue, X. Critical review of the research on the management of prefabricated construction. Habitat Int. 2014, 43, 240-249. [CrossRef]

3. Samari, M.; Ghodrati, N.; Esmaeilifar, R.; Olfat, P. The Investigation of the Barriers in Developing Green Building in Malaysia. Mod. Appl. Sci. 2013, 7. [CrossRef]

4. Olubunmi, O.A.; Xia, P.B.; Skitmore, M. Green building incentives: A review. Renew. Sustain. Energy Rev. 2016, 59, 1611-1621. [CrossRef]

5. Cao, X.; Li, X.; Zhu, Y.; Zhang, Z. A comparative study of environmental performance between prefabricated and traditional residential buildings in China. J. Clean. Prod. 2015, 109, 131-143. [CrossRef]

6. Mao, C.; Shen, Q.; Pan, W.; Ye, K. Major barriers to off-site construction: The developer's perspective in China. J. Manag. Eng. 2015. [CrossRef]

7. Darko, A.; Chan, A.P.C. Review of Barriers to Green Building Adoption. Sustain. Dev. 2016. [CrossRef]

8. Lopez, D.; Froese, T.M. Analysis of Costs and Benefits of Panelized and Modular Prefabricated Homes. Procedia Eng. 2016, 145, 1291-1297. [CrossRef]

9. Demiralp, G.; Guven, G.; Ergen, E. Analyzing the benefits of RFID technology for cost sharing in construction supply chains: A case study on prefabricated precast components. Autom. Constr. 2012, 24, 120-129. [CrossRef]

10. Pujadas-Gispert, E.; Sanjuan-Delmás, D.; Josa, A. Environmental analysis of building shallow foundations: The influence of prefabrication, typology, and structural design codes. J. Clean. Prod. 2018, 186. [CrossRef]

11. Tam, V.W.Y.; Tam, C.M.; Ng, W.C.Y. An Examination on the Practice of Adopting Prefabrication for Construction Projects. Int. J. Constr. Manag. 2007, 7, 53-64. [CrossRef]

12. Clemons, E.K. How information changes consumer behavior and how consumer behavior determines corporate strategy. J. Manag. Inf. Syst. 2008, 25, 13-40. [CrossRef]

13. Hwang, B.G.; Tan, J.S. Green building project management: Obstacles and solutions for sustainable development. Sustain. Dev. 2012, 20, 335-349. [CrossRef]

14. Diamantopoulos, A.; Schlegelmilch, B.B.; Sinkovics, R.R.; Bohlen, G.M. Can socio-demographics still play a role in profiling green consumers? A review of the evidence and an empirical investigation. J. Bus. Res. 2003, 56, 465-480. [CrossRef]

15. Hartmann, P.; Apaolaza Ibáñez, V. Green Value Added, Marketing Intelligence \& Planning; Emerald Group Publishing: Bingley, UK, 2006.

16. Carrington, M.J.; Neville, B.A.; Whitwell, G.J. Why ethical consumers don't walk their talk: Towards a framework for understanding the gap between the ethical purchase intentions and actual buying behaviour of ethically minded consumers. J. Bus. Ethics 2010, 97, 139-158. [CrossRef]

17. Kollmuss, A.; Agyeman, J. Mind the gap: Why do people act environmentally and what are the barriers to pro-environmental behavior? Environ. Educ. Res. 2002, 8, 239-260. [CrossRef] 
18. Luo, L.Z.; Mao, C.; Shen, L.Y.; Li, Z.D. Risk factors affecting practitioners' attitudes toward the implementation of an industrialized building system: A case study from China. Eng. Constr. Archit. Manag. 2015, 22, 622-643. [CrossRef]

19. Volkman, D.A.; Henebry, K. The Use of Incentive Contracting and Firm Reputation. Corp. Reput. Rev. 2010, 13, 3-19. [CrossRef]

20. Grimmer, M.; Bingham, T. Company environmental performance and consumer purchase intentions. J. Bus. Res. 2013, 66, 1945-1953. [CrossRef]

21. Chiang, Y.H.; Chan, E.H.W.; Lok, L.K.L. Prefabrication and barriers to entry-a case study of public housing and institutional buildings in Hong Kong. Habitat Int. 2006, 30, 482-499. [CrossRef]

22. Ajzen, I.; Fishbein, M. Understanding Attitudes and Predicting Social Behaviour; Prentice Hall: Upper Saddle River, NJ, USA, 1980.

23. Ajzen, I. From Intentions to Actions: A Theory of Planned Behavior. In Action Control; Springer: Berlin/Heidelberg, Germany, 1985.

24. Ajzen, I.; Madden, T.J. Prediction of goal-directed behavior: Attitudes, intentions, and perceived behavioral control. J. Exp. Soc. Psychol. 1986, 22, 453-474. [CrossRef]

25. Ajzen, I. The theory of planned behavior. Organ. Behav. Hum. Decis. Process. 1991, 50, 179-211. [CrossRef]

26. Madden, T.J.; Ellen, P.S.; Ajzen, I. A comparison of the theory of planned behavior and the theory of reasoned action. Personal. Soc. Psychol. Bull. 1992, 18, 3-9. [CrossRef]

27. Abzari, M.; Ghassemi, R.A.; Vosta, L.N. Analysing the Effect of Social Media on Brand Attitude and Purchase Intention: The Case of Iran Khodro Company. Procedia Soc. Behav. Sci. 2014, 143, 822-826. [CrossRef]

28. Peng, T.Q.; Zhu, J.J.H.; Tong, J.J.; Jiang, S.J. Predicting internet non-users' adoption intention and adoption behavior. Ann. Allergy Asthma Immunol. 2012, 106, 407-411. [CrossRef]

29. Kumar, B.; Manrai, A.K.; Manrai, L.A. Purchasing behaviour for environmentally sustainable products: A conceptual framework and empirical study. J. Retail. Consum. Serv. 2017, 34, 1-9. [CrossRef]

30. Mufidah, I.; Jiang, B.C.; Lin, S.C.; Chin, J.; Rachmaniati, Y.P.; Persada, S.F. Understanding the Consumers' Behavior Intention in Using Green Ecolabel Product through Pro-Environmental Planned Behavior Model in Developing and Developed Regions: Lessons Learned from Taiwan and Indonesia. Sustainability 2018, 10, 1423. [CrossRef]

31. Peattie, K. Green Consumption: Behavior and Norms. Annu. Rev. Environ. Resour. 2010, 35, 195-228. [CrossRef]

32. Grimmer, M.; Kilburn, A.P.; Miles, M.P. The effect of purchase situation on realized pro-environmental consumer behavior. J. Bus. Res. 2016, 69, 1582-1586. [CrossRef]

33. Manaktola, K.; Jauhari, V. Exploring consumer attitude and behaviour towards green practices in the lodging industry in India. Int. J. Contemp. Hosp. Manag. 2007, 19, 364-377. [CrossRef]

34. Pawaskar, U.S.; Raut, R.D.; Gardas, B.B. Assessment of Consumer Behavior Towards Environmental Responsibility: A Structural Equations Modeling Approach: Analyses the elements of environmental responsibility of consumer. Bus. Strategy Environ. 2017, 27, 560-571. [CrossRef]

35. Cheng, S.; Lam, T.; Hsu, C.H.C. Testing the sufficiency of the theory of planned behavior: A case of customer dissatisfaction responses in restaurants. Int. J. Hosp. Manag. 2005, 24, 475-492. [CrossRef]

36. Wang, S.T. Consumer characteristics and social influence factors on green purchasing intentions. Mark. Intell. Plan. 2014, 32, 738-753. [CrossRef]

37. Conner, M.; Armitage, C.J. Extending the theory of planned behavior: A review and avenues for further research. J. Appl. Soc. Psychol. 1998, 28, 1429-1464. [CrossRef]

38. Han, H.; Hsu, L.T.; Sheu, C. Application of the Theory of Planned Behavior to green hotel choice: Testing the effect of environmental friendly activities. Tour. Manag. 2010, 31, 325-334. [CrossRef]

39. Cheon, J.; Lee, S.; Crooks, S.M.; Song, J. An investigation of mobile learning readiness in higher education based on the theory of planned behavior. Comput. Educ. 2012, 59, 1054-1064. [CrossRef]

40. Becker-Olsen, K.L.; Cudmore, B.A.; Hill, R.P. The impact of perceived corporate social responsibility on consumer behavior. J. Bus. Res. 2005, 59, 46-53. [CrossRef]

41. Han, M.; Wang, B.; Zhang, T. The Environmental Management Incentive Policy of Oil and Gas Field Enterprises Based on Sustainable Development. In Proceedings of the 2011 Asia-Pacific Power and Energy Engineering Conference, Wuhan, China, 25-28 March 2011; IEEE Computer Society: Washington, DC, USA, 2011; pp. 1-5. 
42. Lu, W.; Chen, K.; Xue, F.; Pan, W. Searching for an optimal level of prefabrication in construction: An analytical framework. J. Clean. Prod. 2018, 201, 236-245. [CrossRef]

43. Rashid, M.; Spreckelmeyer, K.; Angrisano, N.J. Green buildings, environmental awareness, and organizational image. J. Corp. Real Estate 2012, 14, 21-49. [CrossRef]

44. Xu, E.M.; Xu, K. The effect of government incentive policy on firm's innovation performance: A multilevel analysis. In Proceedings of the 2010 International Conference on Management Science \& Engineering 17th Annual Conference, Melbourne, Australia, 24-26 November 2010; pp. 1416-1421.

45. Teng, Y.; Li, K.; Pan, W.; Ng, T. Reducing building life cycle carbon emissions through prefabrication: Evidence from and gaps in empirical studies. Build. Environ. 2018, 132, 125-136. [CrossRef]

46. Trafalski, S.; Briffa, T.; Hung, J.; Moorin, R.E.; Sanfilippo, F.; Preen, D.B.; Einarsdóttir, K. Effect of private insurance incentive policy reforms on trends in coronary revascularisation procedures in the private and public health sectors in Western Australia: A cohort study. BMC Health Serv. Res. 2013, 13, 1-8. [CrossRef] [PubMed]

47. Zhang, X.; Shen, L.; Wu, Y.; Qi, G. Barriers to implement green strategy in the process of developing real estate projects. Open Waste Manag. J. 2011, 4, 33-37.

48. Pat, B. Harnessing the power of reputation: Strengths and limits for promoting cooperative behaviors. Evol. Psychol. 2012, 10, 868.

49. Kumar, R. Impediments to Adoption of Green Products: An ISM Analysis. J. Promot. Manag. 2014, 20, 501-520.

50. Bonini, S.; Pavesi, F.; Scotti, M. Financial Analysts and Collective Reputation: Theory and Evidence. Soc. Sci. Electron. Publ. 2011. [CrossRef]

51. Chen, J.H.; Ma, S.H. A dynamic reputation incentive model in construction supply chain. In Proceedings of the 2008 International Conference on Management Science and Engineering 15th Annual Conference Proceedings, Long Beach, CA, USA, 10-12 September 2008; pp. 385-392.

52. Wagner, M.; Schaltegger, S. The Effect of Corporate Environmental Strategy Choice and Environmental Performance on Competitiveness and Economic Performance: An Empirical Study of EU Manufacturing. Eur. Manag. J. 2004, 22, 557-572. [CrossRef]

53. Shrivastava, P. The Role of Corporations in Achieving Ecological Sustainability. Acad. Manag. Rev. 1995, 20, 936-960. [CrossRef]

54. Hart, S.L.; Ahuja, G. Does It Pay to Be Green? An Empirical Examination of the Relationship between Emission Reduction and Firm Performance. Bus. Strategy Environ. 1996, 5, 30-37. [CrossRef]

55. Gao, H.F.; Ren, P.Y.; Wang, J.; Luo, Y.Y.; Tian, W.Q. Study on reputation incentive effect of environmental pollution control in scenic area. Int. J. Environ. Pollut. 2013, 51, 166-175. [CrossRef]

56. Young, W.; Hwang, K.; Mcdonald, S.; Oates, C.J. Sustainable Consumption: Green Consumer Behaviour when Purchasing Products. Sustain. Dev. 2010, 18, 20-31. [CrossRef]

57. Zhao, H.H.; Gao, Q.; Wu, Y.P.; Wang, Y.; Zhu, X.D. What affects green consumer behavior in China? A case study from Qingdao. J. Clean. Prod. 2014, 63, 143-151. [CrossRef]

58. Gifford, R.; Nilsson, A. Personal and social factors that influence pro-environmental concern and behaviour: A review. Int. J. Psychol. 2014, 49, 141-157. [CrossRef] [PubMed]

59. Gong, R.T.; Cai, W.G. A Survey of Consumers' Perspectives on the 2014 Edition of "Green Building Evaluation Criteria": Take Chongqing for Example. In Proceedings of the 2015 International Conference on Construction and Real Estate Management 2015, Luleå, Sweden, 11-12 August 2015; pp. 400-407.

60. Zhang, L.; Zhou, J. The effect of carbon reduction regulations on contractors' awareness and behaviors in China's building sector. J. Clean. Prod. 2016, 113, 93-101. [CrossRef]

61. Cai, D.F.; Wang, T.W.; Ai, C.H. Development of Low-Carbon Economy in Heilongjiang Province Tax Incentive Policy Analysis. Adv. Mater. Res. 2014, 1073-1076, 2683-2686. [CrossRef]

62. Park, M.; Ingawale-Verma, Y.; Kim, W.; Ham, Y. Construction policymaking: With an example of singaporean government's policy to diffuse prefabrication to private sector. KSCE J. Civ. Eng. 2011, 15, 771-779. [CrossRef]

63. Matic, D.; Calzada, J.R.; Eric, M.; Babin, M. Economically feasible energy refurbishment of prefabricated building in Belgrade, Serbia. Energy Build. 2015, 98, 74-81. [CrossRef]

64. Shazmin, S.A.A.; Sipan, I.; Sapri, M. Property tax assessment incentives for green building: A review. Renew. Sustain. Energy Rev. 2016, 60, 536-548. [CrossRef] 
65. Zhang, W.; Lee, M.W.; Jaillon, L.; Poon, C.S. The hindrance to using prefabrication in Hong Kong's building industry. J. Clean. Prod. 2018, 204, 70-81. [CrossRef]

66. Wu, H.; Mao, C.; Liu, G. Market Expectations of Government's Measures to Promote Off-Site Construction in Mainland China: Developers' Perspective; Springer: Berlin/Heidelberg, Germany, 2015; pp. 1053-1063.

67. Hwang, B.G.; Shan, M.; Looi, K.Y. Key Constraints and Mitigation Strategies for Prefabricated Prefinished Volumetric Construction. J. Clean. Prod. 2018, 183, 183-193. [CrossRef]

68. Zhang, X.; Skitmore, M.; Peng, Y. Exploring the challenges to industrialized residential building in China. Habitat Int. 2014, 41, 176-184. [CrossRef]

69. Hair, J.F.; Ringle, C.M.; Sarstedt, M. PLS-SEM: Indeed a Silver Bullet. J. Mark. Theory Pract. 2011, 19, $139-152$. [CrossRef]

70. Ringle, C.M.; Sarstedt, M.; Straub, D. A Critical Look at the Use of PLS-SEM in MIS Quarterly. Soc. Sci. Electron. Publ. 2012, 36. [CrossRef]

71. Qian, Q.; Zhang, L. Impact of regulatory focus on choice of project-governance modes: Role of tolerance of opportunistic behavior. J. Constr. Eng. Manag. 2018, 144, 04018070. [CrossRef]

72. Ali, F.; Omar, R. Determinants of customer experience and resulting satisfaction and revisit intentions: PLS-SEM approach towards Malaysian resort hotels. Asia Pac. J. Innov. Hosp. Tour. 2014, 3, 175-193. [CrossRef]

73. Jin, B.; Hye Kang, J. Purchase intention of Chinese consumers toward a US apparel brand: A test of a composite behavior intention model. J. Consum. Mark. 2011, 28, 187-199. [CrossRef]

74. Wang, D.; Fang, S.; Li, K. Dynamic changes of governance mechanisms in mega construction projects in China: The mediating role of opportunism. Eng. Constr. Archit. Manag. 2019, 26, 723-735. [CrossRef]

75. Dholakia, U.M.; Bagozzi, R.P.; Gopinath, M. How formulating implementation plans and remembering past actions facilitate the enactment of effortful decisions. J. Behav. Decis. Mak. 2010, 20, 343-364. [CrossRef]

76. Chow, W.S.; Chen, Y. Intended belief and actual behavior in green computing in Hong Kong. J. Comput. Inf. Syst. 2009, 50, 136-141.

77. Manstead, A.S.; van Eekelen, S.A. Distinguishing between perceived behavioral control and self-efficacy in the domain of academic achievement intentions and behaviors. J. Appl. Soc. Psychol. 1998, 28, 1375-1392. [CrossRef]

78. Liobikienė, G.; Mandravickaitè, J.; Bernatonienė, J. Theory of planned behavior approach to understand the green purchasing behavior in the EU: A cross-cultural study. Ecol. Econ. 2016, 125, 38-46. [CrossRef]

79. Gollwitzer, P.M. Implemetation Intentions: Strong Effects of Simple Plans. Am. Psychol. 1999, 54, 493-503. [CrossRef]

80. Cacioppe, R.; Forster, N.; Fox, M. A survey of managers' perceptions of corporate ethics and social responsibility and actions that may affect companies' success. J. Bus. Ethics 2008, 82, 681. [CrossRef]

81. Gan, X.; Chang, R.; Jian, Z.; Tao, W.; Zillante, G. Barriers to the transition towards Off-site construction in China: An Interpretive Structural Modeling approach. J. Clean. Prod. 2018, 197, 8-18. [CrossRef]

82. Paul, J.; Modi, A.; Patel, J. Predicting green product consumption using theory of planned behavior and reasoned action. J. Retail. Consum. Serv. 2016, 29, 123-134. [CrossRef]

83. Fan, Z.; Tan, J.; Jian, Y. Reputation incentive or economic incentive? An empirical study on job-hopping behavior of independent directors. Front. Bus. Res. China 2009, 3, 393-412.

84. Chang, C.H. The influence of corporate environmental ethics on competitive advantage: The mediation role of green innovation. J. Bus. Ethics 2011, 104, 361-370. [CrossRef]

(C) 2019 by the authors. Licensee MDPI, Basel, Switzerland. This article is an open access article distributed under the terms and conditions of the Creative Commons Attribution (CC BY) license (http://creativecommons.org/licenses/by/4.0/). 